\title{
TERAJU
}

Teraju: Jurnal Syariah dan Hukum

Volume 02 Nomor 02, September 2020

DOI: https://doi.org/10.35961/teraju.v2i02.161

\section{Riba dalam Pandangan Ibnu Katsir: Sebuah Kajian Normatif}

\author{
Sumarti \\ Universitas Nahdlatul Ulama Yogyakarta \\ sumartiqu@gmail.com
}

\begin{abstract}
Abstrak
Artikel ini ingin mengungkap pendapat dari lbnu Katsir, penafsir ternama yang bermazhab sunni, tentang riba dan proses pengharamannya. Hal ini menjadi penting karena kehalalan atau keharaman suatu perbuatan dalam hukum Islam tidak hanya dilihat dari aspek hasil atau hukum yang sudah jadi, namun lebih jauh harus diketahui proses penetapannya. Titik tekan dari artikel ini adalah bagaimana lbnu Katsir mensintesakan ayat Al-Qur'an dengan beberapa hadis dan mendialogkan dengan pendapat para ulama. Adapun pendekatan yang digunakan dalam riset ini adalah pendekatan normatif yang melihat riba dari ketetapan Penentu Hukum (Allah) melalui nash-nash Al-Qur'an dan Al Hadits. Dari riset ini dapat disimpulkan bahwa proses pengharaman riba seperti proses pada pengharaman khamr, dan hukum riba adalah haram walaupun dalam beberapa kondisi bisa juga dihukumi mubah, sementara keharaman riba disebabkan karena adanya kezaliman.
\end{abstract}

Kata Kunci: Riba, Tafsir Ibnu Katsir, metodologi tafsir.

$$
\begin{aligned}
& \text { ملخص } \\
& \text { يهدف هذا البحث اكتشاف رأي ابن كثير، مفسر مشهور على مذهب أهل السنة، عن } \\
& \text { حكم الربا وعملية تحريمه. ويعتبر هذا الأمر مهما لأن التحليل أو التحريم لعمل في } \\
& \text { الشريعة لم ينظر إليه من حيث هو حلال أو حرام ولكن من حيث عملية إثباته. وما يعد } \\
& \text { مهما في هذا البحث هو طريقة ابن كثير في اندماج الآيات القرآنية والأحاديث النبوية مع } \\
& \text { عرض العلاقة الحوارية بين آراء العلماء. والمقاربة المستخدمة في هذا البحث هي المقابة }
\end{aligned}
$$




$$
\begin{aligned}
& \text { المعيارية التي تنظر إلى الربا بما قد أثبته الله عبر القرآن الكريم والأحاديث. ونتيجة هذا } \\
& \text { البحث هي عملية تحريم الربا تتم بما في الخمر من العملية، ويكون حكمه حراما رغم أنه } \\
& \text { مباح في بعض الأحيان لأوضاع معينة، ومن أسباب تحيمه الظلم. } \\
& \text { الكلمات الرئيسية: الربا، تفسير ابن كير، منهج التفسير }
\end{aligned}
$$

\section{Pendahuluan}

Pembahasan mengenai riba sudah menjadi isu lama terjadi, namun pembahasan tersebut belum menemukan titik terang. Hingga saat ini masih banyak menimbulkan perdebatan di banyak kalangan. Pembahasan riba perlu dikaji ulang lebih mendalam, karena masih banyak kalangan yang belum memahami konsep riba menurut Al-Qur'an, utamanya dari para mufassir.

Tafsir Ibnu Katsir merupakan salah satu di antara kitab tafsir yang pernah wujud dalam khazanah keilmuan Islam, khususnya dalam ranah 'Ulumul Qur'an. Ia merupakan master piece dari seorang tokoh abad ke-8 hijriah yang mencantumkan namanya sendiri dalam judul kitab tafsir ini. Imam Ibnu Katsir menggunakan metode penafsiran al-Qur'an dengan alQur'an. Jika tidak didapatkan langkah di atas, maka digunakanlah hadis Nabi sebagai alat analisis kedua. Ketika tidak ada pada hadis Nabi, maka digunakan langkah ketiga, yaitu ijma' para sahabat, sampai pada kesepakatan para tabi'in.

Langkah-langkah metodologis tafsir Ibnu Katsir di atas sejalan dengan kajian tematik terma tertentu dalam qur'anic studies yang juga selaras dengan prinsip munasabah, keterkaitan satu ayat dengan ayat lain dan juga tafsirul qur'an bil qur'an. ${ }^{1}$ Metode tafsir Ibnu Katsir menganut mazhab Sunni, yang secara global digunakan dalam istinbath bukm dalam

${ }^{1}$ Lihat Abdul Mustaqim, Metode Penelitian Al-Qur'an dan Tafsir, (Yogyakarta: Idea Press, 2015), hlm. 67.
Islam. Tulisan ini akan mencoba mengupas ayat-ayat tentang riba dan asbab nu₹ulnya, beberapa hadis tentang riba, dan langkah-langkah metodologis Ibnu Katsir dalam mengurai masalah riba dengan sintesa hadis-hadis tentang riba tersebut, sehingga kajian tematik ini lebih mudah dipahami secara komprehensif.

\section{Pembahasan}

\section{A. Pengertian Riba}

Secara etimologis, riba berasal dari bahasa Arab dengan akar kata "r-b-w", rabawa-yarbuwu-ribwan. Oleh karena terdapat huruf 'illah (penyakit), maka huruf waw diganti menjadi huruf alif, sehingga menjadi rabaa-yarbuu-ribaa. Kata riba memiliki beberapa pengertian, antara lain bertambah dan tumbuh dalam konteks harta. ${ }^{2}$ Riba mengandung pengertian manfaat atau keuntungan yang diperoleh oleh si pemberi riba dari orang yang berhutang kepadanya.

Dalam Al-Qur'an terdapat beberapa kata yang seakar dengan riba. Meskipun masing-masing kata mempunyai pengertian teknis yang berbeda, tetapi terdapat unsur kesamaan, yaitu "tambahan/lebih". Rabiyan dalam surah al-Ra'd: 17 artinya mengapung di atas, "mengapung" mengambarkan lebih tingginya sesuatu di atas permukaan air. Rabiyan dalam surah al-Haqqah: 10 artinya (siksaan)

2 Lihat Louis Ma'luf, al Munjid fi al Lughah wa al I'lam, Cet. Ke-41, (Beirut: Dar al Masyriq, 2005), hlm. 247. 
yang amat berat. "Siksaan" mengambarkan bertambahnya derita yang tidak dikehendaki. Rabwah dalam surah al-Baqarah: 265 artinya dataran tinggi. "Dataran tinggi" mengambarkan lebih tingginya tanah dimaksud dari permukaan tanah. Arba dalam surah alNahl: 92 artinya lebih banyak. Adapun riba yang dibicarakan dalam tulisan ini adalah riba sebagai kegiatan ekonomi yang menurut pemahaman para ulama' Tafsir dan Fiqh ditetapkan sebagai perbuatan haram. ${ }^{3}$

Secara epistemologis, riba memiliki beberapa pengertian, antara lain, riba adalah tambahan yang tidak terkait dengan ganti yang dijadikan syarat oleh dua orang yang berakad (dalam jual beli). Dalam ilmu ekonomi, riba adalah sejumlah uang yang diberikan oleh peminjam sebagai tambahan atas uang yang dipinjamnya mengikuti syarat-syarat tertentu. ${ }^{4}$ Tambahan yang dimaksud adalah tambahan yang berasal dari usaha haram yang merugikan salah satu pihak dalam satu transaksi. Sekiranya semua bentuk tambahan haram, tentu perdagangan haram. Sementara Islam menghalalkan perdagangan, karena menyangkut kepentingan manusia dan diketahui sebagai hal yang dibenarkan oleh agama. Yang demikian itu karena bersifat dharuri (esensial). ${ }^{5}$

Dalam istilah syariah, riba berarti tambahan yang diberikan oleh debitor kepada kreditor disebabkan oleh penangguhan waktu atau oleh

3 Muh. Zuhri, Riba dalam Al-Qur'an dan Masalah Perbankan, Cet. Ke-1, Jakarta: PT RajaGrafindo Persada, 1996), hlm. 37-38.

4 Majamma' al Lughah al 'Arabiyyah, al Mu'jam al Wasith, cet. Ke-4, (Kairo: Maktabah al Syuruq al Dauliyyah, 2005), hlm. 326.

5 Abu Sura'i Abdul Hadi, Bunga Bank dalam Islam, Alih bahasa oleh M. Thalib, (Surabaya: Al-Ikhlas, 1991), hlm. 21-22. berbedanya jenis barang. ${ }^{6}$ Nampaknya, dengan satu asumsi bahwa prinsip ekonomi Islam adalah keadilan, kemanusiaan, dan tolong menolong, maka larangan riba dalam Al-Qur'an dititikberatkan pada adanya "penganiayaan (zulm)", bahkan pada "tambahan yang diperjanjikan ketika akad" semata. Sebab, tambahan semacam itu tidak mempunyai makna apa-apa kalau tidak disertai dengan sifat lain, seperti "merugikan", atau "menguntungkan". Agaknya, "tambahan" sebagai ciri khas riba yang diterangkan pada ulama hanya merupakan bentuk formal yang tidak terelakkan, sebagai bentuk penindasan kaya atas si miskin. Karena ia hanya bentuk formal, bukan esensial, maka tambahan atas jumlah pinjaman yang dikembalikan belum tentu disebut riba. "Tambahan" yang mendatangkan kerugian/penganiayaan sepihak disebut riba, tetapi yang mendatangkan kesejahteraan semua pihak tidak termasuk riba. ${ }^{7}$

B. Jenis-jenis Riba

Ada beberapa pendapat tentang riba, namun secara umum ada persamaan persepsi yang menegaskan bahwa riba adalah pengambilan tambahan, baik dalam transaksi jual beli maupun pinjam meminjam secara batil atau bertentangan dengan prinsip muamalah dalam Islam. ${ }^{8}$

Menurut Ibnu Abbas r.a. dalam tafsir Ibnu Katsir bahwa riba dibagi dua, yaitu riba yang dibolehkan dan riba yang tidak dibolehkan. Riba yang

${ }^{6}$ Lajnah Pentashihah Mushaf Al-Qur'an, Pembangunan Ekonomi Umat, (Jakarta: Penerbit Aku Bisa, 2012), hlm. 97.

7 Muh. Zuhri, Riba dalam Al-Qur'an dan Masalah Perbankan, ......hlm. 7-8.

8 Muhammad Syafi'i Antonio, Bank Syariah dari Teori Ke Praktik, Cet. Ke-1, (Jakarta: Gema Insani Press, 2001). Hlm. 37. 
tidak boleh adalah riba dalam jual beli. Sedangkan riba yang dibolehkan adalah hadiah dari seseorang yang ingin memberikan sesuatu yang lebih. ${ }^{9}$

Secara garis besar, riba dikelompokkan menjadi dua. Masingmasing adalah riba utang-piutang dan riba jual beli. Kelompok pertama terbagi lagi menjadi riba qardh dan riba jabiliyyah. Adapun kelompok kedua, riba jual beli terbagi menjadi riba fadbl dan riba nasi'ah. $^{10}$

Adapun pengertian masing-masing pembagian riba di atas adalah sebagai berikut :

1. Riba Qardh

Riba Qardh ialah suatu manfaat atau tingkat kelebihan tertentu yang disyaratkan terhadap yang berhutang (muqtaridb).

2. Riba Jabiliyyah

Riba Jabiliyyah ialah utang dibayar lebih dari pokoknya karena si peminjam tidak mampu membayar utangnya pada waktu yang ditetapkan.

3. Riba Fadbl

Riba Fadbl ialah pertukaran antar barang sejenis dengan kadar atau takaran yang berbeda, sedangkan barang yang dipertukarkan itu termasuk dalam jenis barang ribawi.

4. Riba Nasi'ah

Riba Nasiab ialah penangguhan penyerahan atau penerimaan jenis barang ribawi yang dipertukarkan dengan jenis barang ribawi lainnya. Riba dalam nasiah muncul karena adanya perbedaan, perubahan, atau tambahan antara yang diserahkan

9 Imaduddin Abi Al-Fida' Ismail bin Katsir ad-Dimasyqi, Tafsir al-Qur'an al-'Az̧bim, Jilid ke-11, (Kairo: Maktabah Awlad Syeikh li al-Turats, t.t), hlm. 32 .

10 Muhammad Syafi'i Antonio, Bank Syariah dari Teori ke Praktik, ..... hlm. 41. saat ini dan yang diserahkan kemudian.

C. Ayat-ayat tentang Riba dan Asbabun Nuzulnya

Kata riba disebut sebanyak delapan kali dalam empat surah, yaitu al-Baqarah, surah Ali Imran, surah anNisa', dan surah ar-Rum. Tiga surah pertama termasuk dalam surah Madaniyyah yang turun setelah Nabi Muhammad saw hijrah ke Madinah. Sedangkan surah ar-Rum masuk dalam surah Makkiyyah yaitu turun sebelum beliau hijrah. Dengan begitu, ayat pertama yang berbicara tentang riba adalah ar-Rum ayat 39. Pernyataan tentang terhapusnya riba dipaparkan oleh al-Qur'an secara bertahap yaitu QS. ar-Rum: 39, QS. an-Nisa': 160-161, QS. Ali'Imran: 130 dan QS. al-Baqarah: 278-279. ${ }^{11}$

Berikut ini penjelasan tentang riba menurut al-Qur'an berdasarkan kronologi turunnya ayat:

a. Surah Ar-Ruum, ayat 39 :

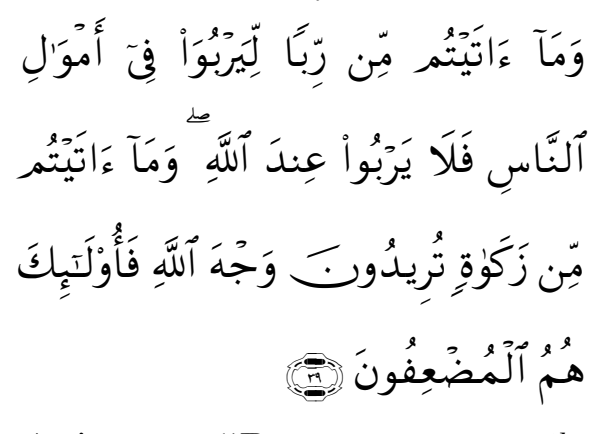

Artinya: "Dan sesuatu riba (tambahan) yang kamu berikan agar dia bertambah pada harta manusia, Maka riba itu tidak menambah pada sisi Allab. dan apa yang kamu berikan berupa zakat yang kamu maksudkan untuk mencapai keridhaan Allah, Maka (yang berbuat demikian) Itulab

11 Dwi Suwiknyo, Kompilasi Tafsir Ayatayat Ekonomi Islam, (Yogyakarta: Pustaka Pelajar, 2010), hlm. 36. 
orang-orang yang melipat gandakan (pahalanya)."

Sebagaimana telah disinggung sebelumnya bahwa surah Ar-Rum termasuk dalam surah Makkiyyah, dan ayat 39 ini adalah ayat yang pertama kali turun berkenaan dengan perkara riba. Ayat ini menjelaskan bahwa riba dianggap oleh orang-orang dapat menambah harta, padahal sejatinya tidaklah demikian di sisi Allah. Tetapi zakatlah yang dapat melipatgandakan harta. Secara tekstual, ayat di atas tidak menyebut riba sebagai perbuatan haram atau tidak diperbolehkan. ${ }^{12}$

Menurut sebagian ulama', riba pada ayat di atas tidak termasuk pada katagori riba yang diharamkan, sementara al-Alusi dan Sayyid Qutb menganggap ia adalah haram. Ibnu Katsir dalam hal ini menganggap boleh, yang ia sebut dengan riba mubah. ${ }^{13}$

b. Surah An-Nisa', ayat 160-161 :

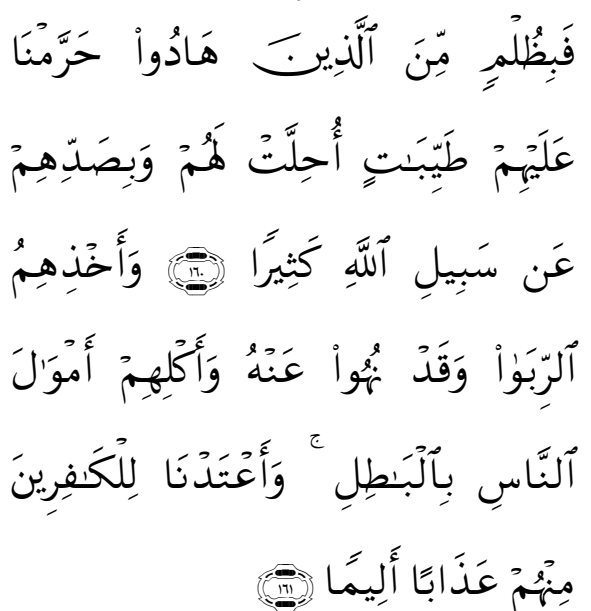

Artinya: "Maka disebabkan kezaliman orang-orang Yabudi, Kami haramkan atas (memakan makanan) yang baik-baik (yang dabulunya) dibalalkan bagi mereka, dan karena mereka banyak menghalangi (manusia) dari jalan Allah. Dan disebabkan mereka memakan riba, padabal Sesunggubnya mereka telah dilarang daripadanya, dan karena mereka memakan harta benda orang dengan jalan yang batil. Kami telab menyediakan untuk orang-orang yang kafir di antara mereka itu siksa yang pedih."

Setelah surah Ar-Rum di atas, ayat selanjutnya yang berbicara tentang riba adalah surah An-Nisa', ayat 161. Ayat ini menjelaskan tentang siksaan Allah kepada orang-orang Yahudi (ayat 160) karena mereka memakan riba. Ayat ini dianggap oleh sebagian besar ulama bahwa turunnya sebelum ayat 130 dari surah Ali Imran.

Di dalam ayat ini, Allah tidak melarang riba kepada kaum Muslimin secara langsung, tetapi secara implisit melarang kepada kaum Yahudi, yang pada akhirnya juga akan berlaku bagi kaum Muslimin. Larangan riba kepada kaum Muslimin bertahap seperti halnya larangan pada minum khamr. ${ }^{14}$

c. Surah Ali Imran, ayat 130 :

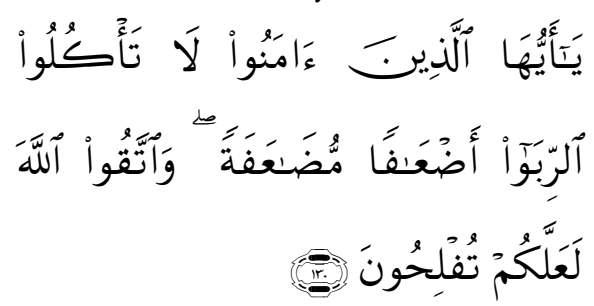

Artinya : "Hai orang-orang yang beriman, janganlah kamu memakan riba dengan berlipat ganda, dan bertakwalah kamu kepada Allah supaya kamu mendapat keberuntungan."

Pada ayat di atas sangatlah jelas larangan Allah terhadap riba, terlebih lagi yang berlipat ganda (adh'afan mudha'afah). Tujuan (khitab) ayat tersebut ditujukan kepada orang-orang

12 Muh. Zuhri, Riba dalam Al-Qur'an dan Masalah Perbankan, ......hlm. 60. 
yang beriman. Riba di sini adalah riba nasi'ah, yang diharamkan selamanya. ${ }^{15}$

d. Surah Al-Baqarah, ayat 275 :
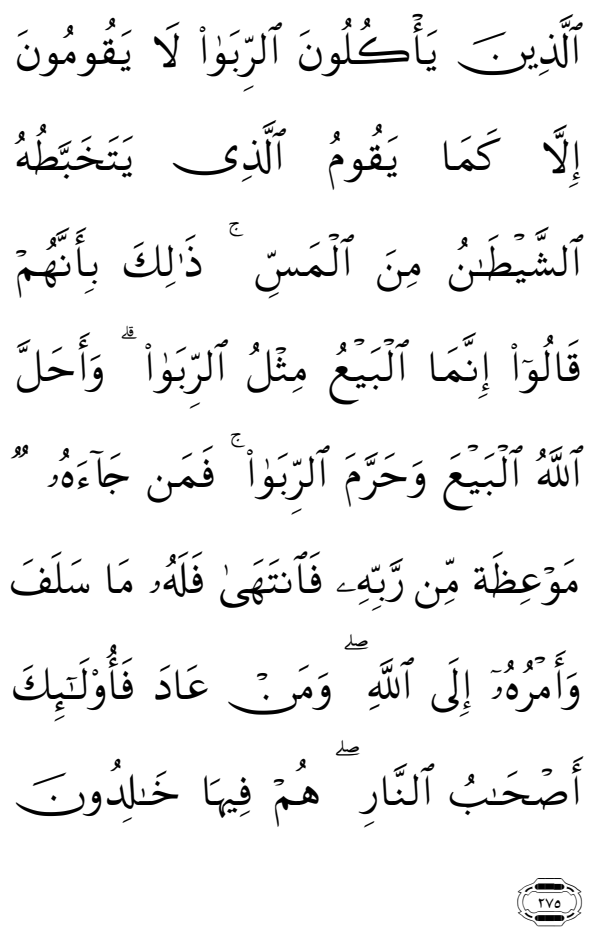

Artinya: "Orang-orang yang makan (mengambil) riba tidak dapat berdiri melainkan seperti berdirinya orang yang kemasukan syaitan lantaran (tekanan) penyakit gila. Keadaan mereka yang demikian itu adalah disebabkan mereka berkata (berpendapat), sesunggubnya jual beli itu sama dengan riba, padahal Allah telah menghalalkan jual beli dan mengharamkan riba. Orang-orang yang telah sampai kepadanya larangan dari Tubannya, lalu terus berbenti (dari mengambil riba), maka baginya apa yang telah diambilnya dabulu (sebelum datang larangan); dan urusannya (terserab) kepada Allah. Orang yang kembali (mengambil riba), maka orang itu adalab penghuni-pengbuni neraka; mereka keekal di dalamnya."

15 Dwi Suwiknyo, Kompilasi Tafsir Ayatayat Ekonomi Islam, .... hlm. 42. e. Surah Al-Baqarah, ayat 276-277 :
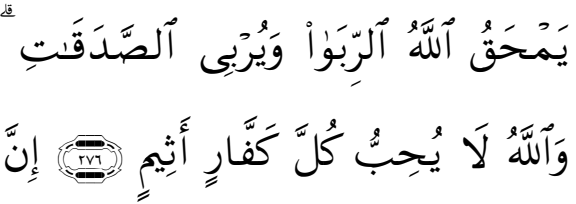

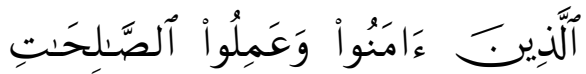

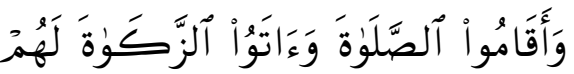

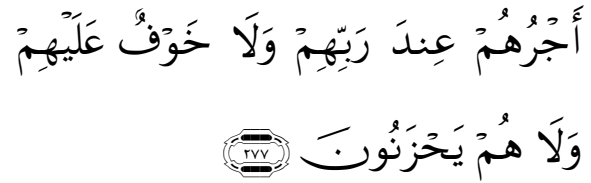

Artinya: "Allab memusnabkan riba dan menyuburkan sedekah, dan Allab tidak menyukai setiap orang yang tetap dalam kekafiran, dan selalu berbuat dosa. Sesunggubnya orang-orang yang beriman, mengerjakan amal saleh, mendirikan shalat dan menunaikan zakat, mereka mendapat pahala di sisi Tubannya. tidak ada kekhawatiran terbadap mereka dan tidak (pula) mereka bersedih hati."

f. Surah Al-Baqarah, ayat 278-279 :

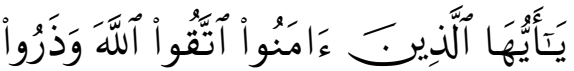

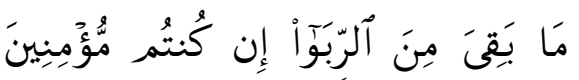

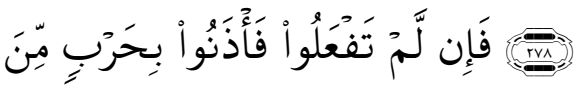

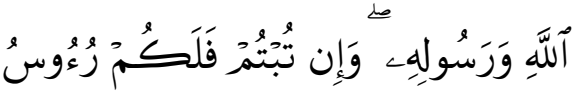

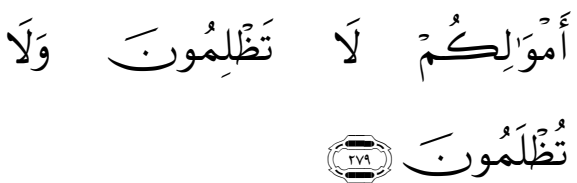

Artinya: "Hai orang-orang yang beriman, bertakwalah kepada Allah dan tinggalkan sisa riba (yang belum dipungut) jika kamu orang-orang yang beriman. Maka jika kamu tidak mengerjakan (meninggalkan sisa riba), 
maka ketahuilah, babwa Allab dan rasul-Nya akan memerangimu. dan jika kamu bertaubat (dari pengambilan riba), maka bagimu pokok hartamu; kamu tidak menganiaya dan tidak (pula) dianiaya."

Kelompok ayat terakhir yang memuat tentang riba secara utuh menggambarkan tentang riba, pelaku riba, dan efek-efek negatif dari perbuatan riba. Secara umum, ayat-ayat di atas turun akibat perbuatan riba yang dilakukan oleh penduduk Mekkah dan penduduk Thaif. ${ }^{16}$

Diturunkannya ayat 278-279 dari surah Al-Baqarah di atas berawal dari laporan Gubernur Itab bin Usaid kepada Rasulullah saw perihal tagihan hutang dengan tambahan riba yang dilakukan Bani Amr kepada Bani Mughirah. Hal ini telah berlangsung lama sejak zaman jahiliyah. Namun, setelah Bani Mughirah masuk Islam, maka mereka menolak seluruh praktik riba yang dilakukan sejak zaman jahiliyah tersebut. ${ }^{17}$

Berdasarkan turunnya ayat di atas, maka seluruh praktik riba, baik kecil apalagi besar, dalam transaksi menjadi haram hukumnya, dan meninggalkan riba merupakan indikasi apakah seseorang benar-benar beriman atau tidak. Jika riba tidak ditinggalkan, maka ancaman untuk diperangi akan segera terwujud. Masalah riba menjadi tolok ukur keadilan dan pemerataan sosial serta tidak ada lagi kezaliman di muka bumi.
D. Beberapa Hadis tentang Riba

1. Shahih Muslim, Kitab al Masaqat, Bab as-Sharf w Bai' az Drabab bil Waraq Naqdan ${ }^{18}$

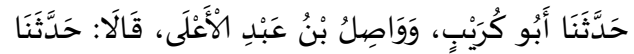

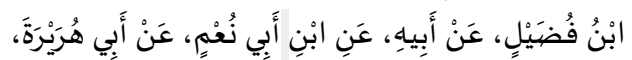

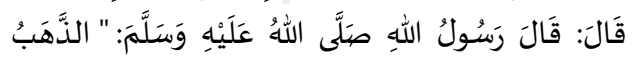

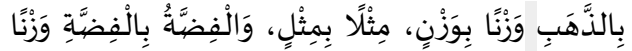

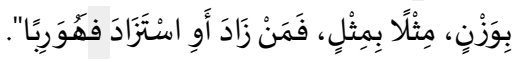
Artinya: "Rasulullah saw bersabda: "Emas dengan emas sama timbangan dan ukurannya, perak dengan perak sama timbangan dan ukurannya. Barangsiapa menambah atau meminta tambah, maka termasuk riba".

Dari hadis di atas, dapat dipahami bahwa transaksi dengan tukar menukar emas atau perak harus sama ukuran dan timbangannya. Jika tidak demikian, maka termasuk katagori riba.

2. Musnad Imam bin Hanbal, no Hadis $10191^{19}$

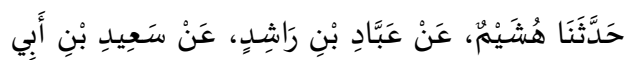

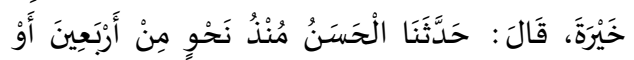

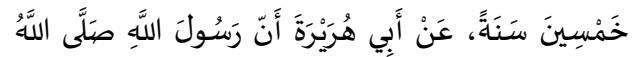

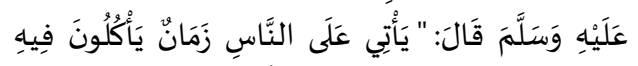

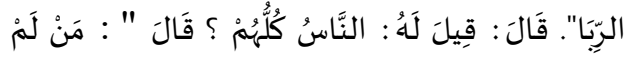

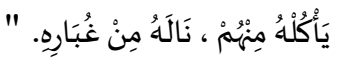
Artinya: "Rasulullah saw bersabda: "Akan datang suatu zaman pada manusia di mana mereka akan memakan riba". Kemudian Baginda ditanya: "Semua manusia?". Baginda menjawab: "Di antara mereka yang tidak makan, akan mendapatkan debunya".

18 http://www.hadithportal.com/hadith1588\&book=2. Akses pada 19 Januari 2016, pukul 17.45. Bdk. Ilfi Nur Diana. Hadis-hadis Ekonomi, (Malang: UIN Malang Press, 2008), hlm. 135.

${ }^{19} \mathrm{http} / /$ /www.ansarsunna.com/vb/showt hread.php?t=34525. Akses pada 02 Januari 2016. Pukul 08.50.
${ }^{16}$ Muh. Zuhri, Riba dalam Al-Qur'an dan Masalab Perbankan, ......hlm. 66.

17 Dwi Suwiknyo, Kompilasi Tafsir Ayatayat Ekonomi Islam, .... hlm. 45. 
Hadis di atas menandaskan bahwa riba adalah masalah yang terus menghiasi perjalanan manusia, seakan-akan manusia tidak akan lepas dari praktik riba, bahkan orang yang tidak memakan riba sekalipun, akan terkena dampaknya. Nampaknya, manusia akan susah menghindari riba. Hal lain yang perlu dicermati adalah bahwa manusia perlu kehati-hatian dalam menjalankan praktik jual beli.

3. Hadis dari Jabir r.a. ${ }^{20}$ روى مسلم (1598) عَنْ جَابٍٍِ، قَالَ: (لَعَنَ رَسُولُ اللَهِ

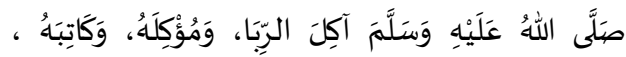

$$
\text { وَشَشَاهِدَيْهِ ) ، وَقَالَ: (هُمْ سَتَوَاءُ) }
$$

Artinya: "Rasulullah saw melaknat pemakan riba, pemberinya, penulisnya, kedua saksinya, mereka semua adalah sama".

Hadis di atas dengan jelas menjelaskan bahwa praktik riba dan pelakunya adalah dilaknat oleh Rasulullah saw. Hal ini menunjukkan bahwa riba adalah haram hukumnya. 4. Hadis dari al Imam Ahmad r.a. ${ }^{21}$

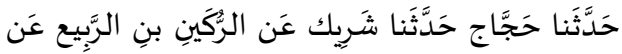

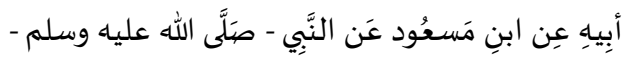

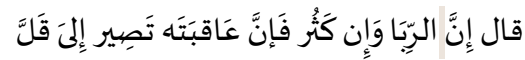

Artinya: "Rasulullab saw bersabda: "Riba itu sekalipun dapat menyebabkan bertambah banyak, tetapi akibatnya akan menjadi berkurang".

Maksud hadis di atas adalah bahwa praktik riba memang dapat mendatangkan keuntungan yang banyak bagi yang melakukannya,

20 https://islamqa.info/ar/202904. Akses pada 02 Januari 2016. Pukul 08.50.

${ }^{21}$ Lihathttp://www.al-quran

alkareem.com/bs/Tefsir/\%D8\%AA $\%$ D $9 \% 81 \% \mathrm{D}$ $8 \% \mathrm{~B} 3 \% \mathrm{D} 9 \% 8 \mathrm{~A} \% \mathrm{D} 8 \% \mathrm{~B} 1 \% \mathrm{D} 8 \% \mathrm{~A} 7 \% \mathrm{D} 8 \% \mathrm{~A} 8 \%$ D9\%86-

$\% \mathrm{D} 9 \% 83 \% \mathrm{D} 8 \% \mathrm{AB} \% \mathrm{D} 9 \% 8 \mathrm{~A} \% \mathrm{D} 8 \% \mathrm{~B} 1 / \mathrm{El}-$ Bekara/276. Akses pada 19 Januari 2016. Pukul 20.35. Lihat pula Ilfi Nur Diana. Hadis-hadis Ekonomi, hlm. 138. tetapi tidak mendatangkan berkah dan akhirnya berkurang.

E. Riba Menurut Tafsir Ibnu Katsir

a. Biografi Singkat Ibnu Katsir

Namanya adalah Ismail bin Katsir. Gelar lengkapnya Ismail bin 'Amr Al-Quraisyi bin Katsir Al-Bashri Ad-Dimasyqi, Imaduddin Abu Al-Fida Al-Hafizh Al-Mubaddits Asy-Syafi'i. Beliau adalah seorang pemikir dan ulama Muslim. Ia lebih dikenal sebagai Ibnu Katsir. Ia lahir pada tahun 1301 M di Busra, Suriah dan wafat pada tahun $1372 \mathrm{M}$ di Damaskus, Suriah. ${ }^{22}$ Mazhab beliau adalah sunni.

Beberapa karyanya antara lain: Jami al-Masanid wa as-Sunan, AlKutub as-Sittah, At-Takmilah fi Mar'ifat as-Sigat wa ad-Dhua'fa wa alMujahal, Al-Mukhtasar, Adillah atTanbih li Ulum al-Hadis, Al-Bidayah wa an Nibayah, Al-Fusul fi Sirah arRasul, Tabaqat asy-Syafi'iyah. Karyanya yang paling terkenal adalah di bidang tafsir, yaitu Tafsir Ibnu Katsir.

b. Metode Penafsiran Ibnu Katsir

Tafsir Ibnu Katsir, dalam menafsirkan al-Qur'an menggunakan langkah-langkah metodis sebagai berikut :

1. Menafsirkan Al-Qur'an dengan Al-Qur'an itu sendiri

2. Menafsirkan Al-Qur'an dengan hadis-hadis Nabi jika di dalam alQur'an tidak dapat menafsirkan, karena Nabi Muhammad saw diperintahkan untuk menerangkan isi Al-Qur'an.

3. Menafsirkan Al-Qur'an dengan pendapat para sahabat (ijma), karena menurut Ibnu Katsir mereka yang mengetahui secara

${ }^{22}$ https://id.wikipedia.org/wiki/Ibnu_Ka tsir. Akses pada 01 Januari 2016, pukul 19.00 
langsung konteks sosial turunnya al-Qur'an (asbab an-nuгu).

4. Selanjutnya al-Qur'an ditafsirkan oleh para tabiin jika ijma' tidak dapat dilakukan.

c. Tafsir tentang Riba dalam AlQur'an

Pada surah Al-Baqarah, ayat 275-278 dijelaskan secara panjang lebar mengenai riba. Dalam surah al-Baqarah ayat 275, Allah swt mengumpamakan orang yang makan dari hasil riba seperti orang yang bangkit dari kuburnya seperti orang gila pada saat mengamuk dan kerasukan setan. Ibnu Kastir menambahkan kondisi mereka sangatlah buruk karena kerasukan setan dan berdiri dalam posisi yang tidak sewajarnya.

Pada sisi lain, Ibnu Katsir menambahkan keterangan dari Ibnu Abbas bahwa mereka yang melakukan riba dibangkitkan pada hari kiamat dalam keadaan gila dan tercekik. Perumpamaan lain yang disampaikan oleh Ibnu Katsir dalam tafsirnya berkenaan dengan pelaku riba adalah hadis manam (melalui isyarat mimpi), yaitu hadis yang diriwayatkan oleh Imam Bukhari dari Samurah bin Jundub bahwa ia bermimpi melihat sungai yang airnya berwarna merah seperti darah. Ada seorang laki-laki yang berenang, dan ada seorang lagi yang mengumpulkan batu. Pada saat lelaki yang berenang mendekati laki-laki yang mengumpulkan batu, dan pada saat itu si pengumpul batu menyumbat batunya pada mulut si perenang yang menganga. ${ }^{23}$

23 Abdullah bin Muhammad bin Abdurrahman bin Ishaq al-Syeikh, Lubab al-Tafsir
Adapun hadis manam/ta'bir ri'ya adalah sebagai berikut: ${ }^{24}$

فأتينا على نهر أحمر مثل الدم، فإذا في الههر رجل

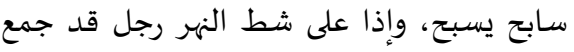

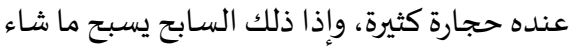

الله أن يسبح، ثم يأتي ذلك الذي قد جدار جمع عنده

الحجارة فيفغر لله فاه فيلقمه حجرا، فينطلق

فيسبح، ثم يرجع إليه كلما رجع إليه، فيفغر له فاه

فيلقماء حجرا.

Secara tidak langsung, dalam hal ini Ibnu Katsir menyatakan bahwa riba itu haram dan pelakunya akan mendapatkan balasan dari Allah, kecuali jika itu terjadi pada zaman jahiliyah atau yang sudah berlalu. Ibnu Katsir menyertakan dalil dari hadis Nabi yaitu : ${ }^{25}$

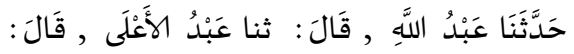

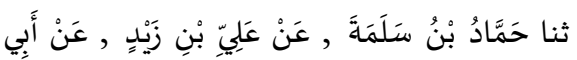

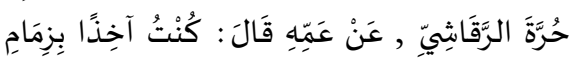

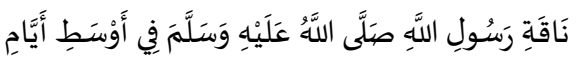

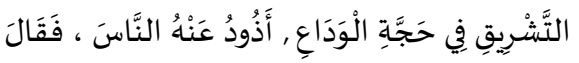
فِيمَا يَقُولُ :

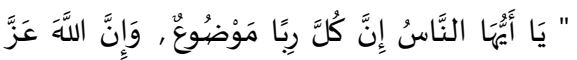

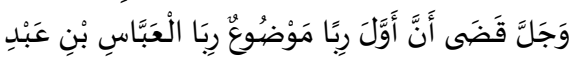

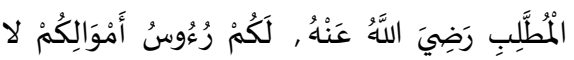
تَظْلِمُونَ وَلا تُظْلَمُونَ.

Pada hadis di atas dijelaskan bahwa praktik riba telah dihapuskan. Allah swt menetapkan bahwa riba yang pertama kali dihapuskan adalah riba 'Abbas bin Abdul Muthalib.

min Ibni Katsir, terj. M. Abdul Ghoffar, EM, Juz 3, (Bogor: Pustaka Imam Asy-Syafi'i, 2001), hlm. 546.

${ }^{24}$ http:/ / library.islamweb.net/newlibrary/ display_book.php?idfrom $=29 \&$ \&idto $=29 \& b k \_n o=1$ 20\&ID=30\#docu. Akses pada 02 Januari 2016, pukul 06.10.

${ }^{25}$ https:/ / library.islamweb.net/hadith/dis play_hbook.php?hflag=1\&bk_no $=1346 \&$ pid $=884$ 075 , akses pada 01 Januari 2016, pukul 22.00. 
Pada lanjutan ayat setelahnya, Allah swt akan memasukkan mereka yang melakukan praktik riba setelah datangnya larangan riba tersebut. Untuk menegaskan ayat di atas, Ibnu Katsir menyertakan hadis yang diriwayatkan oleh Al-Hakim dari Abu Haitsam, yaitu: ${ }^{26}$

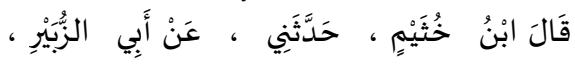

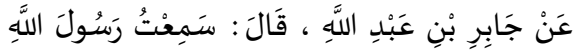

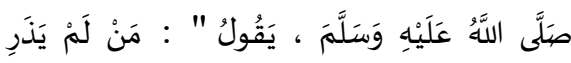

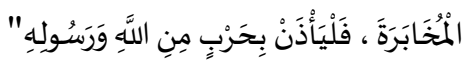

Maksud hadis di atas adalah bahwa orang yang melakukan mukhabarah, maka ia wajib diperangi. Makna mukhabarah ialah menyewakan tanah dengan imbalan sebagian hasil buminya. Demikian juga halnya dengan murabanah, yaitu membeli kurma basah yang masih ada di pohonnya dengan pembayaran kurma kering yang ada di tanah. Demikian pula dengan mubaqalah, yaitu pembelian biji yang masih melekat pada tangkainya di ladang dengan biji yang sudah ada di tanah.

Pada ayat inilah Ibnu Katsir senada dengan pendapat Ibnu Abbas bahwa riba itu dibagi dua, yaitu riba yang tidak boleh atau riba jual beli dan riba boleh (riba mubah), yaitu pemberian hadiah dengan mengharapkan kelebihannya atau pelipatannya. Sementara yang mendapat pahala adalah zakat. Ibnu Katsir menggunakan penafsiran ayat ini dengan ayat yang lain dengan bersandar kepada penafsiran beberapa tokoh mufassir yang

${ }^{26}$ http:/ / library.islamweb.net/hadith/disp lay_hbook.php?bk_no $=184 \&$ pid $=116055 \&$ hid $=29$ 60. akses pada 02 Januari 2016, pukul 06.20. menggunakan penafsiran ayat AlQur'an dengan ayat Al-Qur'an yang lain.

Untuk jenis riba, Ibnu Katsir mengutip hadis yang diriwayatkan oleh Ibnu Majah yang diriwayatkan dari Abdullah bin Mas'ud, bahwa Rasulullah saw bersabda :

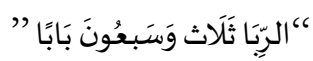

"Riba itu ada tujuh puluh tiga macam" (HR Ibnu Majah)

Hadis di atas juga terdapat tambahannya, yaitu :

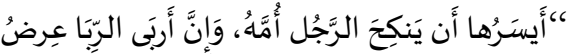

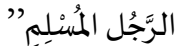

"Yang paling ringan dari riba itu seperti seseorang menikabi ibunya sendiri dan sejahat-jahatnya riba adalab mengganggu kehormatan seorang muslim" (HR. Al Hakim) ${ }^{27}$

Untuk menambah penjelasan tentang keharaman riba, Ibnu Katsir juga menggunakan hadis riwayat Imam Ahmad tentang sulitnya menghindarkan diri dari riba. Ini sebagai peringatan untuk menjauhi

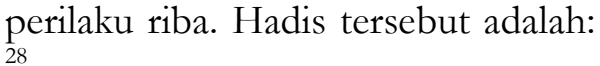

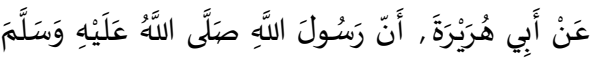

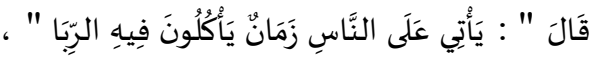

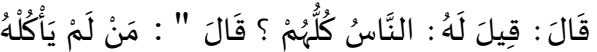

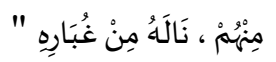

"Akan datang suatu masa di mana manusia banyak memakan riba. Ditanyakan kepada Rasulullah saw : "Apakah manusia keseluruhannya?. Beliau menjawab: "Yang tidak memakannya pun akan terkena debunya". (HR. Ahmad).

27 Abdullah bin Muhammad bin Abdurrahman bin Ishaq al-Syeikh, Lubab al-Tafsir min Ibni Katsir, .......... hlm. 551.

${ }^{28} \mathrm{http}$ / / www.ansarsunna.com/vb/showt hread.php?t=34525. Akses pada 02 Januari 2016. Pukul 08.50. 
Dalam ayat 276 dari surah $\mathrm{Al}-$ Baqarah, Ibnu Katsir mengatakan bahwa Allah menghapus riba, baik secara keseluruhan dari tangan pelakunya maupun mengharamkan keberkatan hartanya, dan ia tidak dapat mengambil manfaat darinya. Bahkan Allah menghilangkannya di dunia dan memberikan hukuman di akhirat.

Penjelasan di atas disertai dengan dalil dari ayat Al-Qur'an, surah Al-Anfaal, ayat 37:

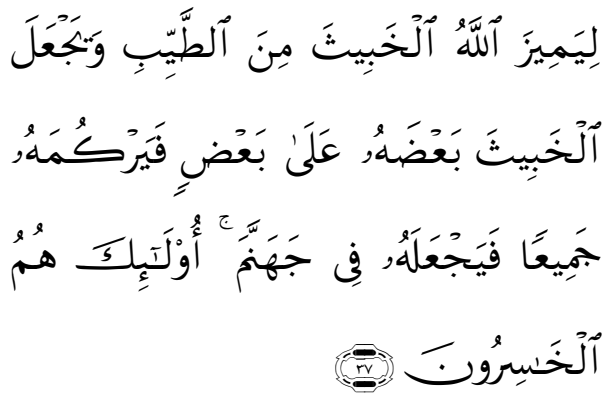

Artinya: "Supaya Allah memisabkan (golongan) yang buruk dari yang baik dan menjadikan (golongan) yang buruk itu sebagiannya di atas sebagian yang lain, lalu kesemuanya ditumpukkan-Nya, dan dimasukean-Nya ke dalam neraka jahannam. mereka Itulah orang-orang yang merugi.

Untuk memulai pembahasan tentang penghilangan riba, Ibnu Katsir menggunakan tafsir Qur'an bil Qur'an sebagai langkah metodis awal dalam menjelaskan akibat dari perbuatan riba.

Kemudian, pada ayat terakhir dari surah al-Baqarah, ayat 278, yang menjelaskan tentang riba, Allah memberikan peringatan kepada orang-orang mu'min untuk meninggalkan sisa riba, yang berupa kelebihan dari pokok yang harus dibayar orang lain. ${ }^{29}$

Untuk menjelaskan panjang lebar tentang peringatan untuk menjauhi riba ini, Ibnu Katsir mencantumkan asbab nuzul ayat ini, bahwa pada zaman jahiliyah telah terjadi praktek riba di kalangan suku-suku. Setelah mereka memeluk agama Islam, salah satu suku di antara mereka, yakni suku Tsaqif, meminta kembali harta riba. Pada saat itu, Mekkah dipimpin oleh Utab bin Usaid yang kemudian mengirimkan surat kepada Rasulullah saw perihal riba ini, maka turunlah ayat di atas.

Ibnu Mardawaih meriwayatkan dari Imam Syafi'i, dari Sulaiman bin Amr, bahwa Rasulullah saw pernah menyatakan bahwa riba dari riba jabiliyah sudah dihapuskan, maka modal harta tidak akan menganiaya dan tidak akan dianiaya.

Pada surah Ali Imran, ayat 130, Allah swt jelas telah melarang melakukan riba dan memakannya dengan berlipat ganda. Hal ini terjadi pada zaman jahiliyah. Dalam hal ini, Ibnu Katsir menyertakan penjelasan ayat ini dengan perkataan orang-orang bahwa pada zaman jahiliyah kala ada dua kemungkinan dalam hal pembayaran hutang. Jika sudah jatuh tempo, kemungkinan hutang dibayar atau dibungakan. Jika dibayar atau dilunasi, maka urusan sudah selesai, tetapi jika tidak dibayar, maka ada ketetapan tambahan untuk jangka waktu tertentu dan kemudian ditambahkan pada pinjaman pokok. Dengan demikian bertambah banyak. ${ }^{30}$

29 Abdullah bin Muhammad bin Abdurrahman bin Ishaq al-Syeikh, Lubab al-Tafsir min Ibni Katsir, juz 3 ........ hlm. 556.

${ }^{30}$ Ibid., juz 6,....... hlm. 137. 
Pada surah an-Nisa', ayat 161, Allah menjelaskan tentang riba yang dilakukan oleh orang-orang Yahudi. Kaum Yahudi selalu membangkang apa yang dilarang oleh Allah, salah satunya adalah perilaku riba, bahkan mereka memakan, mengambil dan menghiasinya dengan berbagai pikatan dan bentuk syubhat lainnya serta memakan harta orang lain secara batil. ${ }^{31}$

Pada surah Ar-Rum, ayat 39, Allah menjelaskan bahwa riba tidak mendatangkan apa-apa, tetapi zakatlah yang dapat melipatgandakan harta. Menurut Ibnu Katsir bahwa barangsiapa yang memberikan sesuatu untuk mendapatkan balasan manusia yang lebih banyak dari apa yang ia berikan, maka perilaku ini tidak mendapatkan pahala di sisi Allah. Hal ini bersandar kepada pendapat Ibnu 'Abbas, Qatadah, Mujahid, Ikrimah, dan lain-lain. Namun, AdDhahhak secara khusus menegaskan bahwa perbuatan ini dibolehkan, walaupun tidak mendapatkan pahala. Tapi Rasulullah saw melarangnya. Hal ini bersandar kepada firman Allah, surah al Muddastsir, ayat 6: "Dan janganlah kamu memberi (dengan maksud) memperoleh balasan yang lebih banyak. ${ }^{32}$

d. Analisis Metode Tafsir Ibnu Kasir tentang Riba

Dari beberapa penafsiran ayatayat riba di atas, dapat dirumuskan metodologi tafsir Ibnu katsir, khususnya tentang riba, sebagai berikut :

1. Tafsir al-Qur'an dengan alQur'an

31 Ibid., hlm. 460.

32 Ibid., Juz 21, hlm. 377.
Ibnu Katsir menggunakan metode tafsir yang pertama ini untuk surah ar-Rum, ayat 39, yaitu dengan menjelaskan penafsiran dari ayat tersebut dengan menambahkan dalil dari ayat al-Qur'an surah al Muddastsir, ayat 6.

2. Tafsir al-Qur'an dengan Hadis Dalam menafsirkan surah AlBaqarah, ayat 275-278, Ibnu Katsir banyak menggunakan hadis-hadis Nabi untuk memperjelas penafsirannya tentang riba, antara lain hadis manam (hadis mimpi), hadis pada saat Rasulullah di hari Tasyriq pada musim haji, hadis tentang larangan praktekpraktek riba, dan lain-lain

\section{Kesimpulan}

Berdasarkan uraian serta penjelasan di atas, dapat diambil kesimpulan sebagai berikut :

1. Dari aspek asbab nuzulnya, proses penentuan keharaman riba mirip seperti proses penentuan keharaman minum khamr. Dimulai dengan munculnya riba dalam masyarakat yang dianggap berguna, kemudian adanya siksaan dari Allah akibat perbuatan riba yang dilakukan kaum Yahudi, dan terakhir pengarahaman parktik riba secara implisit dan panjang lebar bagi kaum Muslimin.

2. Langkah-langkah metodis Tafsir Ibnu Katsir menunjukkan bahwa riba dilarang dalam Islam, walaupun ada juga menurutnya yang termasuk pada katagori riba mubah (pada ayat pertama tentang riba). Hal di atas dapat diketahui dengan melakukan sintesa beberapa ayat dan hadis-hadis Nabi tentang riba.

3. Pada akhirnya, riba hukumnya haram, karena adanya unsur kezaliman. Hal ini diketahui dengan mengelaborasi beberapa kutipan pendapat dari 
beberapa ulama tafsir dalam Tafsir Ibnu Katsir.

\section{Daftar Pustaka}

Abdillah, Kudrat, Maylissabet, M. Taufiq, Kontribusi Babtsul Masail Pesantren di Madura dalam Menghadapi Perkembangan Hukum Islam Kontemporer, Jurnal Perada: Jurnal Studi Islam Kawasan Melayu, 2019.

Antonio, Muhammad Syafi'i, Bank Syariah dari Teori Ke Praktik, Cet. Ke-1, Jakarta: Gema Insani Press, 2001.

Diana, Ilfi Nur, Hadis-hadis Ekonomi, Malang: UIN Malang Press, 2008.

Hadi, Abu Sura'i Abdul, Bunga Bank dalam Islam, Alih bahasa oleh M. Thalib, Surabaya: Al-Ikhlas, 1991.

http://library.islamweb.net/hadith/displa y_hbook.php?bk_no $=184 \&$ pid $=116$ 055\&hid $=2960$

http://library.islamweb.net/newlibrary/di splay_book.php?idfrom $=29$ \&idto $=$ $29 \&$ bk_no $=120 \& I D=30 \#$ docu.

http://www.ansarsunna.com/vb/showthr ead.php?t $=34525$.

http://www.hadithportal.com/hadith$1588 \&$ book $=2$.

https://id.wikipedia.org/wiki/Ibnu_Katsi $\mathrm{r}$.

https://islamqa.info/ar/202904.

https://library.islamweb.net/hadith/displ ay_hbook.php?hflag=1\&bk_no $=13$ 46\&pid $=884075$.

Imaduddin Abi Al-Fida' Ismail bin Katsir ad-Dimasyqi, Tafsir al-Qur'an al'Azhim, Jilid ke-11, Kairo: Maktabah Awlad Syeikh li al-Turats, t.t.

Lajnah Pentashihah Mushaf Al-Qur'an, Pembangunan Ekonomi Umat, Jakarta: Penerbit Aku Bisa, 2012.

Ma'luf, Louis, al Munjid fi al Lughah wa al I'lam, Cet. Ke-41, Beirut: Dar al Masyriq, 2005.

Majamma' al Lughah al 'Arabiyyah, al Mu'jam al Wasith, cet. Ke-4, Kairo:
Maktabah al Syuruq al Dauliyyah, 2005.

Mustaqim, Abdul, Metode Penelitian AlQur'an dan Tafsir, Yogyakarta: Idea Press, 2015.

Suwiknyo, Dwi, Kompilasi Tafsir Ayat-ayat Ekonomi Islam, Yogyakarta: Pustaka Pelajar, 2010.

Syeikh, Abdullah bin Muhammad bin Abdurrahman bin Ishaq al-, Lubab al-Tafsir min Ibni Katsir, terj. M. Abdul Ghoffar, EM, Bogor: Pustaka Imam Asy-Syafi'i, 2001.

Taufiq, M, Optimalisasi Peran Dewan Pengawas Syariah di Lembaga Kenangan Mikro Syariah, Al Huquq: Journal of Indonesian Islamic Economic Law, 2020.

Taufiq, M., dan Muklisin Purnomo, Model Pemberdayaan Aset Wakaf Masjid Secara Produktif Di Masjid Jogokariyan Yogyakarta, Jurnal Perada: Jurnal Studi Islam Kawasan Melayu, 2018.

Zuhri, Muh., Riba dalam Al-Qur'an dan Masalab Perbankan, Cet. Ke-1, Jakarta: PT RajaGrafindo Persada, 1996. 